\title{
Analisis Bauran Promosi Terhadap Keputusan Pembelian Pada Pusat Oleh-Oleh Khas Jambi (Studi Kasus Outlet Temphoyac)
}

\author{
Riko Mappedeceng, Muhammad Amali \\ Fakultas Ekonomi Universitas Batanghari Jambi \\ Corresponding email: rikomappadeceng@gmail.com
}

\begin{abstract}
Abstrak_Penelitian ini bertujuan untuk Mengidentifikasi faktor-faktor bauran pemasaran dan mengetahui strategi promosi yang dilakukan Outlet Temphoyac saat ini, Mengindentifikasi faktor-faktor yang berpengaruh dalam, penyusunan strategi promosi Outlet Temphoyac dan Menganalisis strategi promosi yang lebih tepat bagi Outlet Temphoyac serta memberikan rekomendasi alternatif yang tepat bagi Outlet Temphoyac. Kegiatan penelitian ini dibatasi oleh bidang promosi. Penelitian ini melihat dari sisi perusahaan, bagaimana perusahaan menjalankan strategi promosi, dan membahas sebatas pemilihan program promosi yang paling efektif yang dapat dipertimbangkan berdasarkan faktor-faktor yang mempengaruhi pemilihan program promosi yang di dapat dari hasil wawancara dan Kuesioner. Responden yang dipilih adalah pihak yang terlibat dalam kegiatan promosi Outlet Temphoyac dan konsumen di Outlet Temphoyac, Penelitian ini dianalisis dengan menggunakan regresi linier berganda.dengan hasil $\mathrm{Y}=6,906+0,515$, faktor bauran pemasaran (Marketing Mix) yang terdiri dari kualitas produk, promosi dan saluran distribusi, masing-masing memiliki pengaruh positif signifikan, dan secara bersama-sama memiliki pengaruh yang positif dan signifikan terhadap perilaku pembelian suatu produk/barang.
\end{abstract}

Kata kunci: promosi; pembelian; oleh-oleh; outlet temphoyac

\begin{abstract}
This research aims to identify marketing mix factors and find out the current promotional strategy of Temphoyac Outlets, Identify influential factors in, develop a Temphoyac Outlet promotion strategy and Analyze more appropriate promotional strategies for Temphoyac Outlets and provide appropriate alternative recommendations for Temphoyac Outlets. This research activity is limited by the field of promotion. This research looks at the company's side, how the company executes its promotional strategy, and discusses the selection of the most effective promotional programs that can be considered based on the factors that influence the selection of promotional programs that can be found from interview results and questionnaires. The respondents selected are parties involved in the promotion activities of Temphoyac Outlets and consumers in Temphoyac Outlets, This study was analyzed using multiple linear regressions. with results $Y=6,906+0.515$, marketing mix factors consisting of product quality, promotion and distribution channels, each had a significant positive influence, and together had a positive and significant influence on the purchasing behavior of a product/item.
\end{abstract}

Keywords: promotion; purchase; by; temphoyac outlet

\section{PENDAHULUAN}

Sebagai strategi bisnis, marketing merupakan tindakan penyesuaian suatu organisasi yang berorientasi pasar dalam menghadapi kenyataan bisnis, baik dalam lingkungan mikro maupun lingkungan makro yang terus berubah. Proses pemasaran diharapkan dapat menciptakan nilai untuk pelanggan dan membangun hubungan pelanggan.

Pada dasarnya tujuan dari suatu bisnis adalah untuk menciptakan kepuasan di kalangan konsumen. Terciptanya kepuasan konsumen dapat memberikan beberapa manfaat, di antaranya hubungan antara perusahaan dan konsumen menjadi harmonis, memberikan dasar yang baik bagi pembelia nulang dan terciptanya loyalitas konsumen, dan membentuk suatu rekomendasi dari mulut ke mulut yang menguntungkan perusahaan. Kaitan antara kepuasan konsumen dan kesetiaan konsumen tidak bersifat proporsional. Andaikan kepuasan konsumen dibebri peringkat dengan skala satu sampai lima, maka pada level kepuasan konsumen yang sangat rendah (level satu), para konsumen cenderung menjauhi perusahaan dengan menyebarkan cerita jelek tentang perusahaan tersebut. Pada level dua sampai empat, konsumen agak puas tetapi masih merasa mudah untuk beralih ketika tawaran yang lebih baik muncul. Pada level kelima, konsumen sangat cenderung membeli ulang dan bahkan menyampaikan cerita pujian tentang perusahaan. Kepuasan atau rasa senang yang tinggi menciptakan ikatan emosional dengan merek atau perusahaan tersebut, tidak sekedar suka yang berlebihan.

Faktor pendukung yang menyebabkan Outlet Temphoyac didirikan adalah sedikitnya pusat jajanan atau pusat oleh - oleh khas Jambi. Outlet Temphoyac didirikan pada tahun 2010 yang berlokasi di Jalan Jendral Sudirman No.18. Jambi. Outlet Temphoyac sendiri mulai mengembangkan penjualan dalam skala bisnis yang lebih besar dan mencoba untuk menginformasikan produk jasa kepada masyarakat atau konsumen untuk dapat meningkatkan penjualan perusahaan.

Oleh karena itu, diperlukan media promosi untuk dapat terhubung dengan para konsumen sehingga mampu menguasai lingkup area yang semakin besar 
oleh karena itu diperlukan perluasan promosi. Perusahaan perlu melakukan survei kepuasan pelanggan terhadap kualitas jasa atau produk perusahaan tersebut. Survei ini dapat dilakukan dengan penyebaran kuesioner oleh karyawan perusahaan kepada para pelanggan. Melalui survei tersebut, perusahaan dapat mengetahui kekurangan dan kelebihan produk atau jasa perusahaan tersebut sehingga perusahaan dapat melakukan perbaikan pada hal yang dianggap kurang oleh pelanggan.

\section{Konsep Pemasaran}

Pemasaran secara luas (Kotler, 2009) adalah proses sosial dan manajerial dimana pribadi atau organisasi memperoleh apa yang mereka butuhkan dan inginkan melalui penciptaan dan pertukaran dengan nilai yang lain. Dalam konteks bisnis yang lebih sempit, pemasaran mencakup menciptakan hubungan pertukaran muatan nilai dengan pelanggan yang menguntungkan. Pemasaran didefinisikan sebagai proses dimana perusahaan menciptakan nilai bagi pelanggan dan membangun hubungan yang kuat dengan pelanggan, dengan tujuan menangkap nilai dari pelanggan sebagai imbalannya.

Menurut Kotler dan Keller (2009), untuk dapat memahami fungsi pemasaran, kita perlu memahami serangkaian konsep inti berikut ini:

1. Kebutuhan, keinginan dan permintaan

2. Pasar sasaran, positioning dan segmentasi

3. Saluran pemasaran

4. Rantai pasokan

5. Persaingan

6. Lingkungan pemasaran

Pemasaran jasa adalah bagian dari sistem jasa keseluruhan dimana perusahaan tersebut memiliki semua bentuk kontak dengan pelangannya, mulai dari pengiklanan hingga penagihan; hal ini mencakup kontak yang dilakukan pada saat penyerahan jasa (Lovelock dan Wright, 2007).

\section{Segmentation, Targetting dan Positioning (STP)}

1. Segmentation adalah membagi pasar menjadi kelompok-kelompok kecil dengan kebutuhan, karakteristik atau perilaku yang berbeda yang mungkin memerlukan produk atau bauran pemasaran tersendiri (Kotler dan Armstrong,2008). Sedangkan Tjiptono (2008), menyebutkan bahwa segmentasi pasar adalah proses membagi pasar keseluruhan suatu produk atau jasa yang bersifat heterogen ke dalam beberapa segmen, di mana masing-masing segmennya cenderung bersifat homogen dalam segala aspek. Kotler dan Armstrong (2008), mengklasifikasikan segmentasi pasar berdasarkan empat variabel berikut:

a. Segmentasi Geografis adalah pembagian pasar menjadi unit geografis yang berbeda seperti negara, negara bagian, wilayah, kabupaten, kota dan lingkungan sekitar.

b. Segmentasi Demografis adalah pembagian pasar menjadi kelompok berdasarkan variabel seperti usia, jenis kelamin, ukuran keluarga, siklus hidup keluarga, pendapatan, pekerjaan, pendidikan, agama, ras, generasi dan kebanggan.

c. Segmentasi Psikografis adalah pembagian pasar menjadi kelompok berbeda berdasarkan kelas sosial, gaya hidup atau karakteristik kepribadian.

d. Segmentasi Perilaku adalah pembagian pasar menjadi kelompok berdasarkan pengetahuan, sikap, penggunaan atau respons konsumen terhadap sebuah produk.

2. Targeting adalah proses mengevaluasi daya tarik masing-masing segmen pasar dan memilih satu atau lebih segmen untuk dimasuki (Kotler dan Armstrong, 2008). Pada umumnya, penetapan target pasar bisa dilaksanakan pada beberapa tingkat yang berbeda, seperti yang dijelaskan di bawah ini:

a. Pemasararan massal atau tanpa diferensiasi merupakan bentuk strategi cakupan pasar dimana perusahaan memutuskan untuk mengabaikan perbedaan segmen pasar dan mengejar keseluruhan pasar dengan satu tawaran.

b. Pemasaran tersegmentasi atau terdiferensiasi merupakan strategi cakupan pasar dimana perusahaan memutuskan untuk menargetkan beberapa segmen pasar dan merancang penawaran terpisah bagi masing-masing segmen.

c. Pemasaran terkonsentrasi atau ceruk merupakan strategi cakupan pasar dimana perusahaan mengejar pangsa besar salah satu atau beberapa segmen atau ceruk (niche).

d. Pemasaran mikro merupakan praktek penghantaran produk dan program pemasaran khusus untuk kebutuhan dan keinginanindividual tertentu dan kelompok pelanggan setempat, termasuk pemasaran lokal dan pemasaran individual.

3. Positioning adalah pengaturan produk untuk menduduki tempat yang jelas, berbeda dan diinginkan dibandingkan produk pesaing dalam pikiran konsumen sasaran (Kotler dan Armstrong, 2008). Sedangkan Tjiptono (2008), mendefenisikan positioning sebagai upaya identifikasi, pengembangan dan komunikasi keunggulan yang bersifat khas dan unik sedemikian rupa sehingga produk dan jasa perusahaan dipersepsikan lebih superior dan khusus (disctinctive) dibandingkan produk dan jasa para pesaing dalam benak pasar sasaran.

\section{Strategi Pemasaran}

Strategi adalah sarana bersama dengan tujuan jangka panjang yang hendak dicapai. Strategi bisnis mencakup ekspansi geografis, diverivikasi, akuisisi, 
pengembangan produk, penetrasi pasar, pengetatan, divestasi, likuidasi, dan usaha patungan atau joint venture. Strategi pemasaran merupakan pernyataan (baik secara implisit maupun eksplisit) mengenai bagaimana suatu merek atau lini produk mencapai tujuannya (Tjiptono, 2008).

Menurut Kotler (2005), strategi pemasaran adalah logika pemasaran dan berdasarkan unit bisnis diharapkan dapat mencapai sasaran pemasarannya. Strategi pemasaran terdiri dari pengambilan keputusan tentang biaya pemasaran perusahaan, bauran pemasaran dan alokasi pemasaran. Pada dasarnya strategi pemasaran memberikan arah dalam kaitannya dengan variabelvariabel seperti segmentasi pasar sasaran, positioning, elemen bauran segmentasi pasar dan biaya bauran pemasaran.

\section{Bauran Pemasaran}

Para pemasar menggunakan sejumlah alat untuk mendapatkan tanggapan yang diinginkan dari pasar sasaran mereka. Alat-alat itu membentuk bauran pemasaran. Bauran pemasaran menurut Kotler (2005) adalah seperangkat alat pemasaran yang digunakan perusahaan untuk mencapai tujuan pemasarannnya dalam pasar sasaran. Dalam pemasaran bauran pemasaran merupakan alat yang dapat digunakan produsen untuk mempengaruhi sikap dan tindakan konsumen, selain itu bauran pemasaran juga sebagai penentu keberhasilan pemasaran perusahaan.

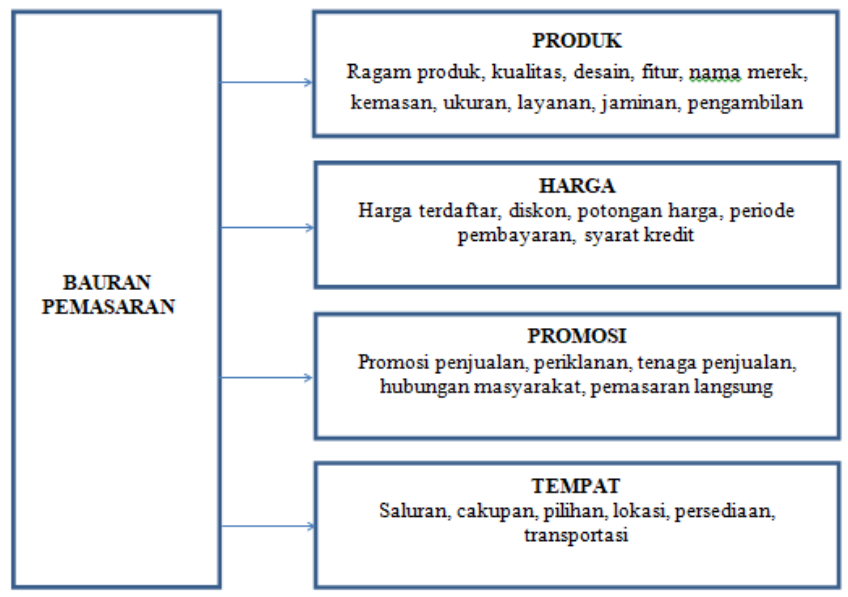

Gambar 1. Bauran pemasaran atau $4 \mathrm{P}$

\section{Promosi}

Pemasara modern memerlukan lebih dari sekedar mengembangkan produk yang baik, menawarkan dengan harga yang menarik dan membuatnya mudah di dapat oleh pelanggan sasaran. Perusahaan harus mampu berkomunikasi dengan para pelanggan yang ada sekarang dan pelanggan potensial, pengecer, pemasok, pihak-pihak yang memiliki kepentingan pada perusahaan tersebut, dan masyarakat umum.
Menurut Kotler dan Armstrong (2008) promosi adalah berbagai kegiatan yang dilakukan oleh produsen untuk mengkomunikasikan manfaat dari produknya, membunjuk, dan mengingatkan para konsumen sasaran agar membeli produk tersebut. Promosi merupakan penentu keberhasilan suatu strategi pemasaran, selain produk, harga, dan distribusi. Betapun berkualitasnya suatu produk, bila konsumen belum pernah mendengarnya maka produk tersebut tidak akan berguna bagi mereka dan tidak akan dibeli. Beberapa faktor yang menyebabkan perlunya pelaksanaan promosi adalah:

1. Jumlah konsumen potensial yang semakin meningkat

2. Persaingan antar perusahaan meningkat

3. Adanya kelesuan-kelesuan ekonomi

4. Adanya perkembangan-perkembangan ekonomi yang pesat dimana kegiatan pemasaran tidak hanya berhenti setelah produk dikembangkan, ditentukan harganya dan distribusikan kepada konsumen, tetapi lebih jauh lagi produk tersebut harus dikomunikasikan kepada calon konsumen dengan cara promosi.

\section{Promotional Mix (Bauran Promosi)}

Tugas pemasar adalah merencanakan aktivitasaktivitas pemasaran dan membentuk program pemasaran yang terintegrasi penuh untuk menciptakan, mengkomunikasikan, dan menghantarkan nilai kepada pelanggan. Aktivitas- aktivitas tersebut merupakan sarana bauran pemasaran dari 4 jenis yang luas yaitu produk, harga, tempat dan promosi. Promosi merupakan salah satu unsur dalam bauran pemasaran, istilah promosi digunakan untuk mendeskripsikan komunikasi dengan pelanggan atau calon pelanggan.

Menurut Shimp (2003) komunikasi pemasaran merespresentasikan gabungan semua unsur dalam pemasaran merek yang memfasilitasi terjadinya pertukaran dengan menciptakan suatu arti yang disebarluaskan kepada pelanggan atau klien.

Menurut Shimp (2003) bentuk-bentuk utama dari bauran promosi dijabarkan sebagai berikut:

1. Penjualan perorangan (personal selling) adalah bentuk komunikasi antar individu dimana tenaga penjual/wiraniaga menginformasikan, mendidik, dan melakukan persuasi kepada calon pembeli untuk membeli produk dan jasa perusahaan.

2. Iklan (advertising) merupakan suatu bentuk dari komunikasi masa yang bersifat non-personal dan dinilai oleh perusahaan bisnis, organisasi nirlaba, atau individu yang diidentifikasikan dengan berbagai cara dalam pesan iklan.

3. Promosi penjualan (sales promotion) terdiri dari semua kegiatan pemasaran yang mencoba merangsang terjadinya aksi pembelian suatu produk yang cepat atau terjadinya pembelian dalam waktu singkat. 
4. Publikasi biasanya dilakukan dalam bentuk berita atau komentar editorial mengenai produk atau jasa dari sebuah perusahaan.

5. Pemasaran langsung (direct marketting) adalah sistem pemasaran yang bersifat interaktif yang memanfaatkan satu atau beberapa media iklan untuk menimbulkan respon yang terukur atau transaksi di sembarang lokasi.

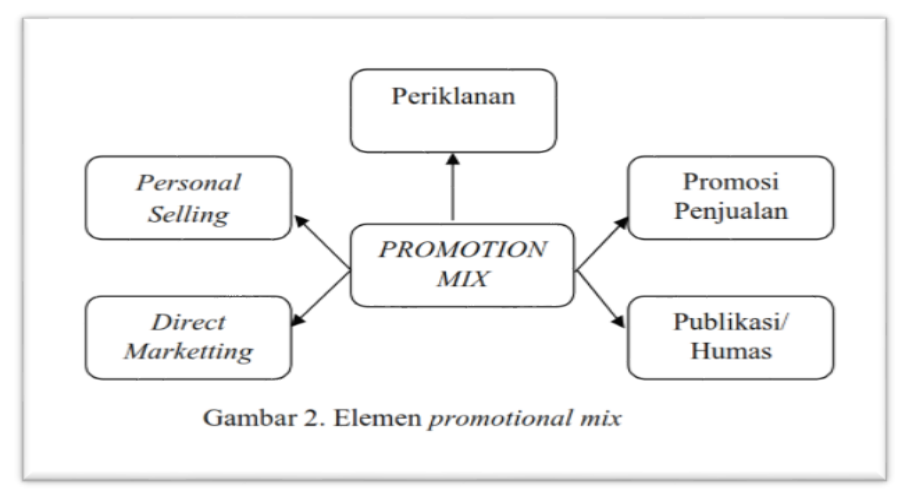

\section{Tujuan Promosi}

Menurut Angipora (2002) secara mendasar tujuan promosi dapat diuraikan sebagai berikut:

1. Menginformasikan

2. Mempengaruhi dan membunjuk pelanggan sasaran

3. Mengingatkan

\section{Faktor-faktor yang Mempengaruhi Keputusan Bauran Promosi}

Menurut Tjiptono (2008) faktor-faktor yang mempengaruhi bauran promosi dikelompokkan menjadi lima faktor yaitu:

1. Produk

2. Pasar

3. Pelanggan

4. Anggaran promosi

5. Bauran Pemasaran

\section{Hipotesis} berikut:

Hipotesis dalam penelian ini adalah sebagai

Ho = Bauran Promosi tidak berpengaruh secara signifikan terhadap Keputusan Pembelian Konsumen.

$\mathrm{H} 1$ = Bauran Promosi berpengaruh secara signifikan terhadap Keputusan Pembelian Konsumen.

\section{METODE}

\section{Jenis dan Sumber Data}

Data yang digunakan pada penelitian ini adalah data primer dan data sekunder. Waktu penelitian dimulai dari bulan Februari sampai bulan Agustus 2020

\section{Metode Pengumpulan Data}

Teknik pengumpulan data yang digunakan dalam penelitian ini adalah sebagai berikut:

\section{Kuesioner}

Tabel 1. Penilaian Skala Likert

\begin{tabular}{lll}
\hline \multicolumn{1}{c}{ Alternatif } & Kode & $\begin{array}{l}\text { Bobot/Nilai } \\
\text { Positif }\end{array}$ \\
\hline Setuju/Selalu/Sangat Positif & SS & 5 \\
Setuju/Sering/Positif & S & 4 \\
Ragu-ragu/Kadang-kadang/Netral & KS & 3 \\
Tidak Setuju/Hampir Tidak Pernah & TS & 2 \\
Sangat Tidak Setuju/Tidak Pernah & STS & 1 \\
\hline
\end{tabular}

\section{Studi Pustaka (Library Research)}

Data sekunder melalui metode ini diperoleh dengan browsing di internet, membaca berbagai literatur, hasil kajian dari peneliti terdahulu, catatan perkuliahan, serta sumber-sumber lain yang relevan.

\section{Populasi dan Sampel}

Adapun populasi dalam penelitian ini adalah Konsumen Outlet Temphoyac yang akan menggunakan produk pada periode penelitian. Karena tidak adanya kepastian jumlah populasi dalam penelitian. Maka disini penulis melakukan penarikan sampel dalam rangka memudahkan penelitian ini.

Ukuran sampel dalam penelitian ini mengacu pada teori yang di kemukakan oleh prawira (2010) yang merekomendasikan jumlah sampel minimal adalah 5 kali dari jumlah item pertanyaan yang terdapat di kuesioner. Indicator dalam penelitian ini terdiri dari 2 variabel penelitian terdiri dari 1 variabel bebas dan 1 variabel terikat.

\section{Metode Analisis Data}

Dalam penelitian ini penulis akan menganalisis data yang diperoleh secara Deskriptif Kualitatif dan Kuantitatif.

\section{HASIL DAN PEMBAHASAN}

Metode pengumpulan data dilakukan dengan cara menyebarkan kuesioner ini kepada 100 responden. Kuesioner ini di berikan langsung kepada responden yang pernah memebeli produk di Outlet Thempoyac

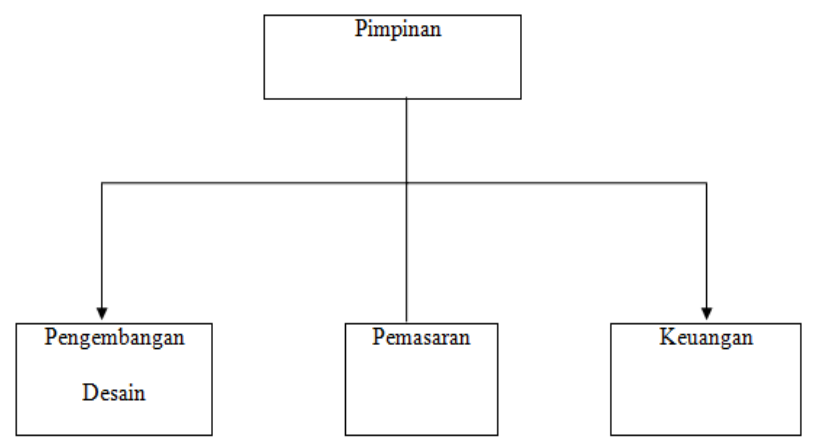

Gambar 3. Bagan Struktur Organisasi Gerai Temphoyac Jambi

Sumber : Outlet Temphoyac Jambi, tahun 2018 
Riko Mappedeceng dan Muhammad Amali, Analisis Bauran Promosi Terhadap Keputusan Pembelian Pada Pusat Oleh-Oleh Khas Jambi (Studi Kasus Outlet Temphoyac)

\section{Deskripsi Frekuensi Responden}

Frekuensi responden dalam penelitian ini dideskripsikan berdasarkan jenis kelamin dan lingkup sebagai berikut:

\section{Deskripsi responden berdasarkan jenis kelamin}

Berdasarkan hasil identifikasi data yang berjumlah 100 responden, maka dalam penelitian ini dapat diketahui bahwa frekuensi responden berdasarkan jenis kelamin adalah $43 \%$ (43 orang) berjenis kelamin Lakilaki dan 57\% (57 orang) berjenis kelamin Perempuan. Dengan demikian dapat dikemukakan bahwa jumlah responden Perempuan dalam penelitian ini lebih dominan (57\%) dari pada jumlah responden Laki-laki (43\%). Hasil identifikasi frekuensi responden berdasarkan jenis kelamin dapat dilihat sebagai berikut:

Tabel 2. Frekuensi Responden Berdasarkan Jenis Kelamin

\begin{tabular}{ccc}
\hline Jenis Kelamin & Jumlah & Persentase \\
\hline Laki-laki & 43 & $43 \%$ \\
Perempuan & 57 & $57 \%$ \\
Total & 100 & $100 \%$ \\
\hline
\end{tabular}

Sumber: Data Responden yang diolah

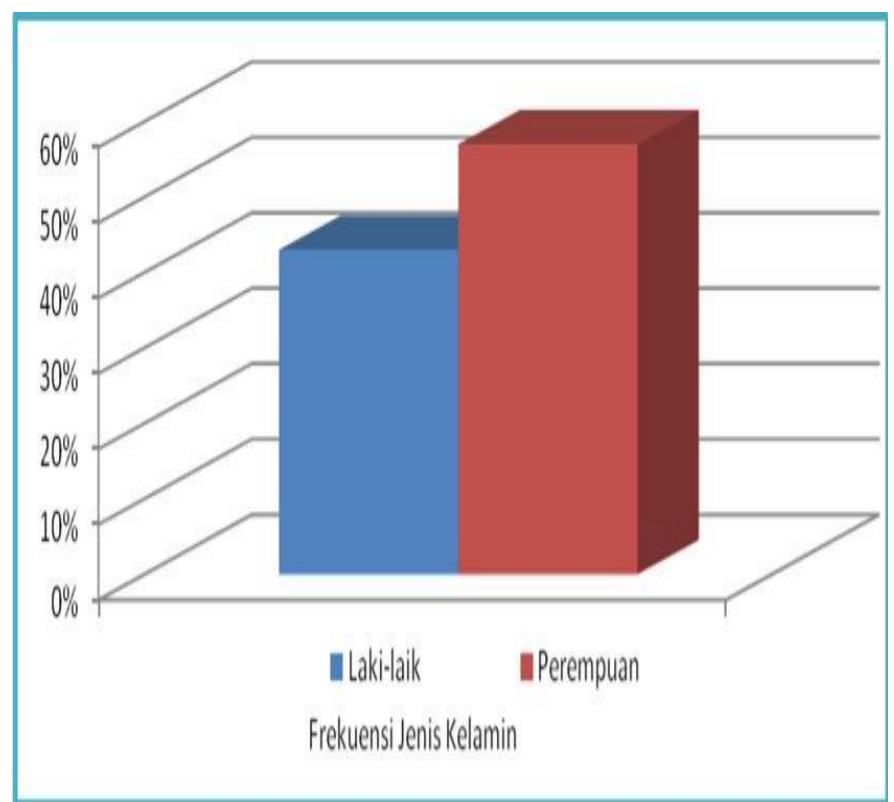

Gambar 4. Frekuensi Responden Berdasarkan Jenis Kelamin Sumber: Data Responden yang diolah

\section{Analisis Deskriptif Statistik}

Analisis deskriptif statistik dalam penelitian ini dilakukan untuk mengintepretasikan skor masing-masing variabel yang terdiri dari variabel bauran pemasaran (Marketing Mix), dan variabel Keputusan Pembelian, dengan cara mengkategorisasikan ke dalam 3 kelas yaitu tinggi, sedang, dan rendah. Pengkategorisasian tersebut dilakukan berdasarkan nilai Mean (M) dan nilai Standar Deviation (SD) yang dihitung dengan menggunakan program SPSS Analyze Descriptive Statistics Frequencies. adapun hasil penghitungan yang telah dilakukan adalah sebagai berikut:
Tabel 3. Hasil Analisis Deskriptif Statistik Frekuensi

\begin{tabular}{lll}
\hline & $\begin{array}{l}\text { Bauran Pemasaran } \\
\text { (Marketing Mix) }\end{array}$ & $\begin{array}{l}\text { Keputusan } \\
\text { Pembelian }\end{array}$ \\
\hline Mean & 55,05 & 35,27 \\
Median & 55,00 & 35,00 \\
Mode & 54 & 35 \\
Std. Deviation & 7,737 & 5,543 \\
Vairance & 59,866 & 30,724 \\
Minimum & 37 & 19 \\
Maximum & 75 & 50
\end{tabular}

Sumber: Data Responden yang diolah

Hasil penghitungan tersebut digunakan untuk melakukan deskripsi data variabel Bauran Pemasaran (Marketing Mix) dan Keputusan Pembelian, sebagai berikut:

\section{Bauran Pemasaran (Marketing Mix)}

Variabel bauran pemasaran (Marketing Mix) diukur menggunakan 4 indikator meliputi indikator produk terdiri dari 4 butir pernyataan/pertanyaan, harga 3 butir pernyataan/pertanyaan, saluran distribusi 5 butir pernyataan/pertanyaan, dan promosi 3 butir pernyataan/pertanyaan, dengan masing-msing jawaban berada pada rentang skor 1 sampai dengan 5. Data hasil penghitungan variabel baruan pemasaran (Marketing Mix) dalam penelitian ini di kategorikan ke dalam 3 interval kelas dengan kriteria batasan kelas sebagai berikut:

\begin{tabular}{lccc}
\hline Tinggi : $(\mathrm{M}+1 \mathrm{SD}) \leq \mathrm{X}$ & \multicolumn{2}{c}{$=62,787 \leq \mathrm{X}$} \\
\hline $\begin{array}{l}\text { Sedang : } \\
\leq \mathrm{X}<62,787\end{array}$ & $(\mathrm{M}-1 \mathrm{SD}) \leq \mathrm{X}<(\mathrm{M}+1 \mathrm{SD})$ & $=47,313$ \\
\hline $\begin{array}{l}\text { Rendah : } \\
\text { 47,313 }\end{array}$ & $\mathrm{X}<(\mathrm{M}-1 \mathrm{SD})$ & $\mathrm{X}$ & $<$ \\
\hline
\end{tabular}

Berdasarkan kriteria tersebut, maka frekuensi penilaian responden dalam penelitian ini di deskripsikan sebagai berikut:

Tabel 4. Frekuensi Penilaian Responden Berdasarkan Variabel Bauran Pemasaran

\begin{tabular}{llll}
\hline Interval & Keterangan & Frekuensi & Persentase \\
\hline $62,787 \leq X$ & Tinggi & 15 & $15 \%$ \\
\hline $47,313 \leq X<62,787$ & Sedang & 68 & $68 \%$ \\
\hline$X<47,313$ & Rendah & 17 & $17 \%$ \\
\hline Jumlah & & 100 & $100 \%$ \\
\hline
\end{tabular}

Sumber: Data Responden yang diolah. 
Riko Mappedeceng dan Muhammad Amali, Analisis Bauran Promosi Terhadap Keputusan Pembelian Pada Pusat Oleh-Oleh Khas Jambi (Studi Kasus Outlet Temphoyac)

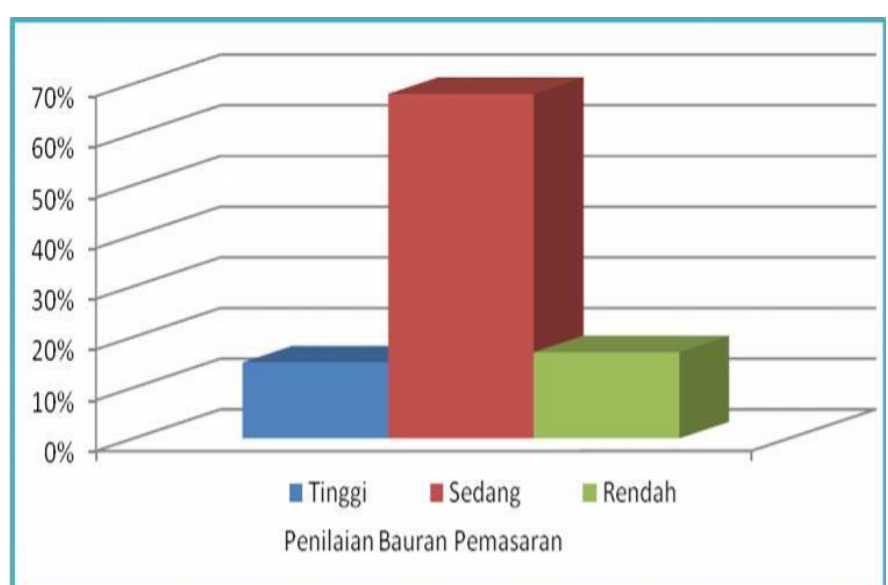

Gambar 5. Frekuensi Penilaian Responden Berdasarkan Variabel Bauran Pemasaran

Sumber: Data Responden yang diolah.

Berdasarkan tabel dan gambar di atas, dapat dilihat bahwa penilaian bauran pemasaran (Marketing Mix) oleh responden yang merupakan kategori tinggi berjumlah $15 \%$, kategori sedang berjumlah $68 \%$ dan kategori rendah berjumlah $17 \%$. Dengan demikian dapat dikemukakan bahwa penilaian responden berdasarkan variabel bauran pemasaran (Marketing Mix) adalah termasuk dalam kategori sedang.

\section{Keputusan Pembelian}

Variabel Keputusan Pembelian diukur menggunakan 4 indikator meliputi indikator pengenalan masalah terdiri dari 2 butir pernyataan/pertanyaan, pencarian informasi 2 butir pernyataan/pertanyaan, evaluasi alternatif 2 butir pernyataan/pertanyaan, dan keputusan pembelian 2 butir pernyataan/pertanyaan, dengan masing-msing jawaban berada pada rentang skor 1 sampai dengan 5 .

Data hasil penghitungan variabel Keputusan Pembelian dalam penelitian ini di kategorikan ke dalam 3 interval kelas dengan kriteria batasan kelas sebagai berikut:

\begin{tabular}{lcc}
\hline Tinggi : $(\mathrm{M}+1 \mathrm{SD}) \leq \mathrm{X}$ & \multicolumn{2}{c}{$=40,813 \leq \mathrm{X}$} \\
\hline $\begin{array}{l}\text { Sedang : } \\
\leq \mathrm{X}<40,813\end{array}$ & $(\mathrm{M}-1 \mathrm{SD}) \leq \mathrm{X}<(\mathrm{M}+1 \mathrm{SD})$ & $=29,727$ \\
\hline $\begin{array}{l}\text { Rendah : } \\
29,727\end{array}$ & $\mathrm{X}<(\mathrm{M}-1 \mathrm{SD})$ & $\mathrm{X}$
\end{tabular}

29,727

Berdasarkan kriteria tersebut, maka frekuensi penilaian responden dalam penelitian ini di deskripsikan sebagai berikut:

Tabel 5. Frekuensi Penilaian Responden Berdasarkan Variabel Keputusan Pembelian

\begin{tabular}{llll}
\hline Interval & Keterangan & Frekuensi & Persentase \\
\hline $40,813 \leq \mathrm{X}$ & Tinggi & 12 & $12 \%$ \\
\hline $29,727 \leq \mathrm{X}<40,813$ & Sedang & 76 & $76 \%$ \\
\hline $\mathrm{X}<29,727$ & Rendah & 12 & $12 \%$ \\
\hline Jumlah & & 100 & $100 \%$ \\
\hline
\end{tabular}

Sumber: Data Responden yang diolah.

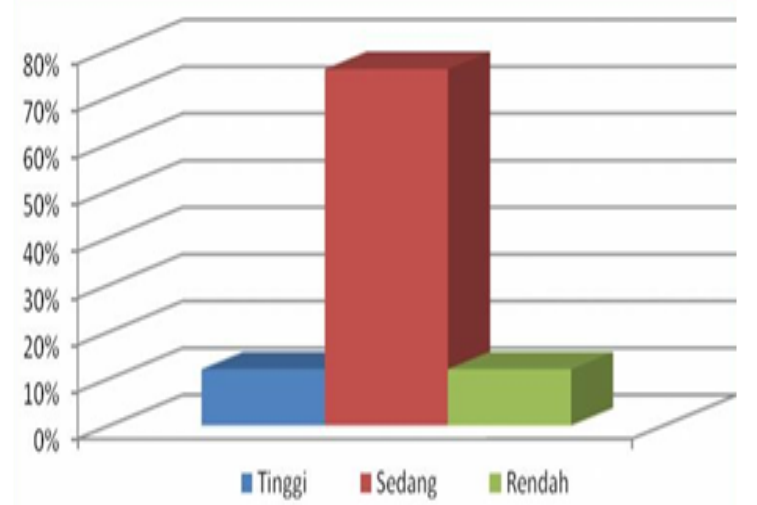

Gambar 6. Frekuensi Penilaian Responden Berdasarkan Variabel Keputusan Pembelian

Sumber: Data Responden yang diolah.

Berdasarkan tabel dan gambar di atas, dapat dilihat bahwa penilaian responden tentang Keputusan Pembelian Produk Tempoyac yang merupakan kategori tinggi berjumlah $12 \%$, kategori sedang berjumlah $76 \%$ dan kategori rendah berjumlah $12 \%$. Dengan demikian dapat dikemukakan bahwa penilaian responden berdasarkan variabel Keputusan Pembelian adalah termasuk dalam kategori sedang.

\section{Pengujian Prasyarat Analisis Uji normalitas data}

Tabel 6. Output Uji Normalitas Data

\begin{tabular}{lrc}
\hline & $\begin{array}{l}\text { Bauran } \\
\text { pemasaran }\end{array}$ & $\begin{array}{l}\text { Keputusan } \\
\text { Pembelian }\end{array}$ \\
\hline Kormogorov-Smirnov Z & 0,955 & 0,994 \\
\hline Asymp.sig.(2-tailed) & 0,321 & 0,277 \\
\hline
\end{tabular}

Dari tabel output dapat diketahui bahwa nilai Signifikansi (Asymp Sig) secara berturut-turut adalah 0,321, 0,277 (nilai signifikansi > 0,05), maka Ho diterima. Dengan demikian dapat dikatakan bahwa distribusi data, bauran pemasaran (Marketing mix), dan Keputusan Pembelian memiliki data yang berdistribusi normal.

\section{Uji Linearitas}

Tabel 7. Hasil Uji Linearitas

\begin{tabular}{lllc}
\hline Variabel & F Hitung & F tabel & Kondisi \\
\hline $\mathrm{X} \rightarrow \mathrm{Y}$ & 2,368 & 2,699 & $\mathrm{~F}_{\mathrm{h}}<\mathrm{F}_{\mathrm{t}}=$ Linear \\
\hline \multicolumn{4}{c}{ Sumber: Data Responden yang diolah. }
\end{tabular}

Keterangan:

$\mathrm{X} \rightarrow \mathrm{Y}=$ pengaruh hubungan linear antara variabel bauran pemasaran dan perilaku kunsumen.

Nilai F hitung < F tabel $(2,368<2,699)$ maka Ho diterima. Dengan demikian dapat dikemukakan bahwa data dalam penelitian ini memiliki hubungan linear. 


\section{Uji multikolinieritas}

Tabel 8. Hasil Uji Multikolinieritas

\begin{tabular}{llll}
\hline Variabel & Tolerance & VIF & Kesimpulan \\
\hline $\begin{array}{l}\text { Bauran } \\
\text { pemasaran }\end{array}$ & 0,315 & 3,175 & $\begin{array}{l}\text { Tidak terjadi } \\
\text { multikolinieritas }\end{array}$ \\
\hline
\end{tabular}

Dari tabel diatas dapat diketahui bahwa nilai tolerance masing-masing variabel bebas lebih besar dari 0,1 dan VIF kurang dari 10, sehingga dengan demikian dapat dilihat bahwa analisis regresi dalam penelitian ini tidak terjadi multikolinieritas.

\section{Uji Heteroskedastitas}

Uji heteroskedastitas dilakukan dengan menggunakan program SPSS model regresi dengan hasil sebagai berikut:

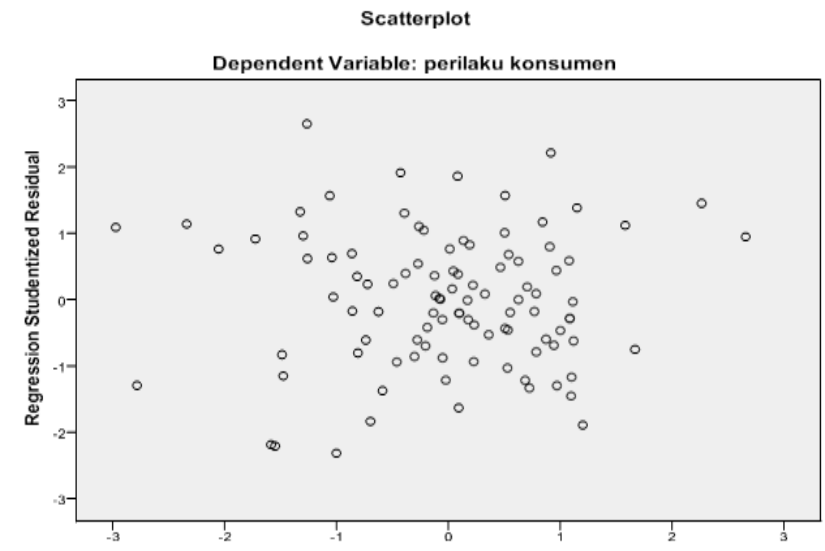

Regression Standardized Predicted Value

Gambar 7. Hasil Uji Heteroskedastitas Menggunakan Program SPSS

Sumber: Data Responden yang diolah.

\section{Pengujian Hipotesis}

Tabel 9. Hasil Analisis Regresi X Terhadap Y

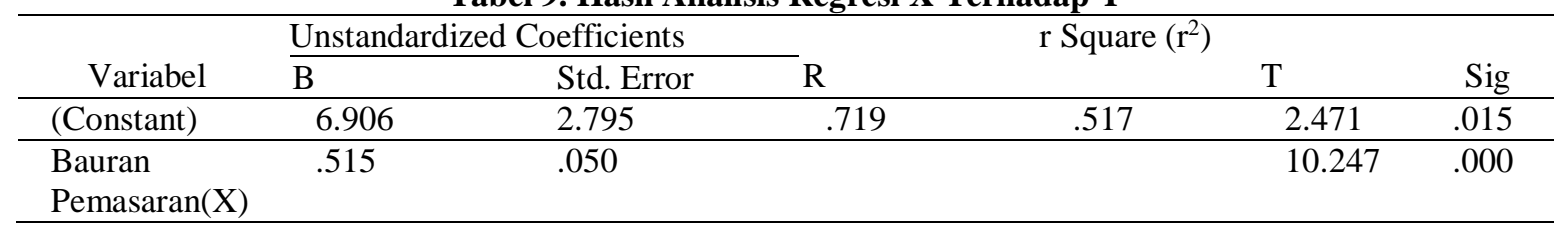

Sumber: Data Responden yang diolah.

Pengaruh Bauran Pemasaran (Marketing Mix) Terhadap Keputusan Pembelian Hasil dalam penelitian ini mendukung hipotesis yang menyatakan bahwa bauran pemasaran (Marketing Mix) berpengaruh positif terhadap Keputusan Pembelian Produk di Outlet Thempoyac. Hal ini ditunjukkan oleh nilai t hitung yang lebih besar dari nilai $t$ tabel yaitu 10,247 >1,984 dan memiliki nilai signifikansi $<0,005$, besarnya nilai tersebut menunjukkan bahwa bauran pemasaran (Marketing Mix) berbengaruh signifikan terhadap Keputusan Pembelian. Dari hasil analisis juga diperoleh nilai koefisien korelasi (r) sebesar 0,719 yang berarti bahwa pengaruh bauran pemasaran (Marketing Mix) terhadap Keputusan Pembelian adalah erat. Sedangkan nilai koefisien determinasi (r2) yang diperoleh adalah sebesar 0,517 menunjukkan adanya pengaruh positif bauran pemasaran (Marketing Mix) terhadap Keputusan Pembelian, hal ini berarti pula bahwa Keputusan Pembelian Produk di Outlet Thempoyac dipengaruhi oleh variabel bauran pemasaran (Marketing Mix) sebesar $51,7 \%$, sedangkan sisanya $(48,3 \%)$ dipengaruhi oleh variabel lain yang tidak dimasukkan dalam analisis uji hipotesis ini. Persamaan garis regresi yang diperoleh dalam analisis ini adalah $\mathrm{Y}=6,906+0,515 \mathrm{X}$, hal ini menunjukkan bahwa jika bauran pemasaran (Marketing Mix) naik 1 satuan, maka Keputusan Pembelian juga naik sebesar 0,515. Salah satu penelitian yang menunjukkan adanya pengaruh positif bauran pemasaran (Marketing Mix) terhadap Keputusan Pembelian adalah penelitian yang dilakukan oleh Suhartatik (2009). Hasil penelitian ini menunjukkan bahwa faktor bauran pemasaran (Marketing Mix) yang terdiri dari kualitas produk, promosi dan saluran distribusi, masing-masing memiliki pengaruh positif signifikan, dan secara bersama-sama memiliki pengaruh yang positif dan signifikan terhadap perilaku pembelian suatu produk/barang.

\section{SIMPULAN}

Berdasarkan hasil observasi dalam penelitian ini dapat dikemukakan bahwa jika dilihat dari faktor bauran pemasaran (Marketing Mix) dengan mengamati kondisi produk di Outlet Thempoyac, biaya, ada tidaknya iklaniklan tentang Produk di Outlet Thempoyac, serta kondisi jumlah penjual sebagai agen distribusi pulsa Produk di Outlet Thempoyac di sekitar lingkungan pelanggan, maka sebagian pelanggan Produk di Outlet Thempoyac di Jambi menunjukkan perilaku positif dan sebagian lagi menunjukkan perilaku negatif. Hal ini dapat dikatakan demikian dengan uraian sebagai berikut:

1. Pertama, berdasarkan faktor produk, hasil observasi menyatakan bahwa pelanggan Produk di Outlet Thempoyac di Jambi menunjukkan perilaku positif karena produk Thempoyac di Outlet Thempoyac terkesan lebih modern dan lengkap dibandingkan dengan yang lain. Selain itu dengan menggunakan Produk di Outlet Thempoyac pelanggan juga lebih 
dimudahkan karena pelanggan lebih mudah mencari outletnya.

2. Kedua, berdasarkan faktor harga, hasil observsi menyatakan bahwa pelanggan Produk di Outlet Thempoyac di Jambi menunjukkan perilaku positif karena pelanggan merasa bahwa harga yang dibayarkan sebanding dengan manfaat yang ia dapatkan. Sedangkan perilaku negatif yang ditunjukkan pelanggan berdasarkan faktor harga adalah pada sebagian pelanggan yang merasa bahwa setelah pindah ke merk / penjual lain, harga sedikit lebih tinggi. keluhan pelanggan tersebut dimungkinkan karena pada waktu pembelian pelanggan tidak menyadari bahwa adany abarang pengganti.

3. Ketiga, berdasarkan faktor promosi, hasil observasi menyatakan bahwa sebagian besar pelanggan Produk di Outlet Thempoyac di Jambi menunjukkan perilaku negatif karena promosi dan sosialisasi yang dilakukan Thempoyac masih sangat kurang, hal ini dapat dilihat dari kurang adanya iklan, sosialisasi, maupun penyuluhan yang dilakukan pihak Thempoyac sehingga pelanggan kurang tertarik dengan Produk di Outlet Thempoyac. Sebagian besar pelanggan yang menggunakan Produk di Outlet Thempoyac adalah pelanggan loyal yang memang telah menggunakan barang di Outlet Thempoyac. Sedangkan sebagian pelanggan yang melakukan migrasi adalah atas dasar ingin ikut-ikutan dengan pelanggan yang lain tanpa di dasari oleh pertimbangan yang matang karena minimnya informasi, sehingga pada akhirnya pelanggan kecewa.

4. Keempat, berdasarkan faktor distribusi, hasil observasi menyatakan bahwa sebagian besar pelanggan Produk di Outlet Thempoyac di Jambi menunjukkan perilaku positif karena tempat-tempat penjualan Produk di Outlet Thempoyac mudah dijangkau oleh pelanggan. Pelanggan dapat membeli kapanpun mereka butuhkan, bahkan hanya dengan melakukan sms dan online shopping kepada penjual maka pesanan pelanggan akan dikirim. Proses pemesanan maupun pembelian juga dirasa cukup mudah, pelanggan dapat membeli secara on-line ataupun mendatangi otlet - outlet thempoyac.

\section{DAFTAR PUSTAKA}

Angipora PM. 2002. Dasar-dasar Pemasaran Edisi 2. Jakarta (ID) : PT. Raja Grafindo Persada.

Jefkins Frank F. 1997. Periklanan. Jakarta (ID): Erlangga.

Kotler. 2005. Manajemen Pemasaran (Terjemahan, Jilid I). Jakarta (ID) : PT. Indeks Kelompok Gramedia.

Kotler P dan Armstrong G. 2008. Prinsip-prinsip Pemasaran (Buku 1, Edisi 12). Jakarta (ID): Erlangga.

Kotler P dan Keller KL. 2009. Manajemen Pemasaran Edisi 13 Jilid 1. Jakarta (ID): Erlangga.
Kurniaty S. 2007. Analisis Strategi Promosi Pada Perusahaan Jasa Event Organizer (Studi Kasus CI Production PT.CB Media Komunika). [Skripsi]. Bogor (ID): IPB Press.

Lovelock $\mathrm{CH}$ dan Wright LK. 2007. Manajemen Pemasaran Jasa (terjemahan). Jakarta (ID): PT. Indeks Kelompok Gramedia.

Marimin. 2004. Tehnik dan Aplikasi Pengambilan Keputusan Kriteria Majemuk. Jakarta (ID): Grasindo.

Marimin dan Maghfiroh N. 2011. Aplikasi Tehnik Pengambilan Keputusan Dalam Manajemen Rantai Pasok. Bogor (ID): IPB Press.

Rachmanda Y. 2009. Analisis Strategi Bauran Promosi AJB Bumiputera 1912 Cabang Siliwangi Bogor. [Skripsi]. Bogor (ID): Institut Pertanian Bogor.

Rangkuti F. 1997. Analisis SWOT: Teknik Membedah Kasus Bisnis. Jakarta (ID):PT. Gramedia Pustaka Utama.

Rismiati C \& Suratno B. 2001. Pemasaran Barang dan Jasa. Yogyakarta (ID): Kanisius.

Sari OL. 2006. Strategi Promosi Pada Perusahaan Jasa Konsultan Teknologi Informasi (Studi Kasus pada PT. Mutiara Solusindo). [Skripsi]. Bogor (ID): Institut Pertanian Bogor.

Shimp AT. 2003. Periklanan Promosi Prospek Aspek Tambahan Komunikasi Pemasaran Terpadu Jilid I. Jakarta (ID): Erlangga.

Soekresno 2010. Sukses Berbisnis Salon Muslima. Jakarta (ID): PT. Indeks Kelompok Gramedia.

Tjiptono F. 2008. Strategi Pemasaran Edisi III. Yogyakarta (ID): Andi offset

Umar A. 2001. Peranan E-Business dalam Upaya Meningkatkan Penjualan (Studi Kasus pada Jaringan Global Resources). [Tesis]. Bogor (ID): Institut Pertanian Bogor. 